\title{
The Enthusiasm of Citizens to Get Involved in Bersih Desa Tradition
}

\author{
$1^{\text {st }}$ Takdilla Adi Ramadan \\ Social Studies Program \\ Universitas Negeri Malang \\ Malang, Indonesia \\ takdilla22@gmail.com
}

\author{
$2^{\text {nd }}$ Agus Purnomo \\ Social Studies Program \\ Universitas Negeri Malang \\ Malang, Indonesia \\ agus.purnomo.fis@um.ac.id
}

\author{
$3^{\text {rd }}$ I Dewa Putu Eskasasnanda \\ Social Studies Program \\ Universitas Negeri Malang \\ Malang, Indonesia \\ eskasasnanda.fis@um.ac.id
}

\begin{abstract}
Tradition is something that is done continuously in the same form. Every region in Indonesia has a different tradition. One is the Bersih Desa Tradition that embodies a sense of gratitude for the blessings given by God for the bountiful harvest at the local villagers. Glanggang Village Society is one of the people who inherited the Bersih Desa Tradition. The tradition that routinely held once a year to make people enthusiastic Glanggang village to enliven and preserve it. The purpose of this article to describe the shape of the enthusiasm of the villagers Glanggang in the implementation of Bersih Desa Tradition. The method used is qualitative. Data obtained through interviews. The data analysis using interactive analysis. Results showed that the public's enthusiasm was high as seen from some form of a given society that contributes money, human resources and time, the contribution of consumption, as well as the presence of the public.
\end{abstract}

\section{Keywords: enthusiasm, Bersih Desa}

\section{INTRODUCTION}

Tradition is something that is done continuously in the same form. Something handed down from the past to the present and from the old generation to the new generation of so-called tradition [1]. More specifically, a tradition carried out by the community can be seen from the form of the tradition itself. The culture that has at least three states, namely as a complex of ideas, as a complex activity, and as a result of social work [2]. A form of culture as an intricate pattern of human activity is a tradition.

Every region in Indonesia has a different tradition, as noted [3]. Indonesia is an archipelago with the diversity of art and vibrant culture. One of the traditions that exist in Indonesia is the tradition of the Bersih Desa. Bersih Desa tradition is a manifestation of gratitude for favors given by God for the bountiful harvest at the local villagers. The Bersih Desa tradition carried village the villagers to ask for salvation to God [4].

Glanggang village community, District of Pakisaji is one of the people who inherited the Bersih Desa tradition. Glanggang village community always carries out the tradition once a year exactly after the padi harvest. Villagers carry out once a year after the harvest season [5]. The tradition conducted annually by involving the whole community concerned [6].

Tradition always routinely implemented, making the Glanggang village communities are very enthusiastic enliven and preserve ceremony. In the tradition into a community resource share is a form of togetherness and desire to preserve tradition [7]. Therefore, people express enthusiasm in various forms, including participation. Community participation in organizing the net traditions of the village there are three kinds [8]. The first is shaped material, the second form of participation in the physical form of power, and the third form of participation is mental and emotional involvement, demonstrated community to participate without coercion. The existence of the village community's enthusiasm for implementing Bersih Desa Glanggang this charming village to study. The research will focus on knowing the form of the enthusiasm of the villagers in implementing Bersih Desa tradition..

\section{METHOD}

A qualitative approach was used to describe the shape of the enthusiasm of the villagers Glanggang involved in the activities of the Bersih Desa. Determination of the subject based on his involvement in a previous activity. Data were collected by indepth interview technique that aims to know about the enthusiasm of the villagers Glanggang in the implementation of Bersih Desa tradition [9]. Data were analyzed using the interactive analysis technique that consists of four stages, data collecting, presenting, reduction, and verification [10].

\section{RESULTS AND DISCUSSION}

The enthusiasm of the villagers Glanggang in organizing the Bersih Desa tradition manifested itself in various ways. The shape of the enthusiasm shown that people can be donations of material and non-material. The donations are given voluntarily without coercion and sanctions from anyone. The attitude of the public showed their enthusiasm.

Public enthusiasm in Glanggang form donations of money. Donations of money are used to clean the smooth running tradition of the village. The nominal net contribution to the implementation of the village is not determined the amount, and there is no compulsion to pay. However, residents with a willingness and awareness always donate money to do the tradition. Participation in the form of money is a form of enthusiasm to expedite the efforts that are used to process attainment needs. Participation money is a form of participation to expedite efforts for the achievement of society [11]. Dues money from the people is what will be used by the committee in the implementation of tradition as supporters of the event hire equipment. 
In addition to financial donations, the contribution of labor has also become one of the public's enthusiasm for the implementation of the tradition. On the implementation of Bersih Desa, community cooperation to work together in making statue symbolizing evil (Jolen) (Fig 1) being one example of the contribution of labor. People who work also took time after work to help with the process. The community realized that the energy needed for the implementation that they took the time.

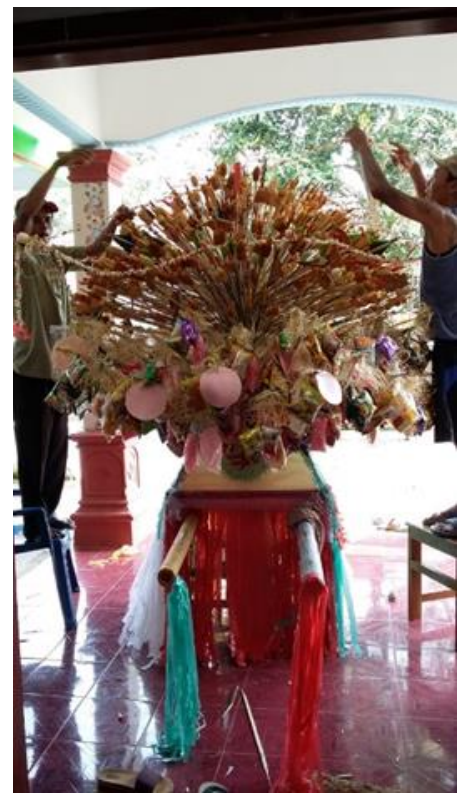

Fig 1. Making Jolen

Enthusiasm shape in the form of human resources and time are intended to ease the burden together. Enthusiasm in the form of power can see from the participation of citizens in voluntary work including cleaning the environment, cleaning the cemetery of the village, and the tomb of a village elder (Punden). Also, the public's enthusiasm demonstrates with mutual assistance in the manufacture of Jolen. Cooperation on Bersih Desa tradition to strengthen ties between communities [12]. People are also willing to sacrifice the time to do everything for smooth Bersih Desa and attend. Contribution of labor in the implementation of the indispensable traditions [13]. That is because as a collective, mutual help activities and social work will be able to create a job will be lighter and quickly resolved [14].

Moreover, enthusiasm also manifested in the form of donations consumption. This enthusiasm can call with a donation of property which is usually indicated by providing consumption and cigarette. Donations from village communities to Bersih Desa activity can be goods or consumption [7]; [15]. The enthusiasm in kind usually has been recognized by the public without their orders. With the social system still prioritizing family, many citizens who volunteer to donate food, drinks or cigarettes at their disposal to support the manufacture of Jolen cooperation.

Another enthusiasm demonstrated by the presence of the community in the implementation of Bersih Desa tradition. Although not donate material and nonmaterial directly, but the number of spectators who attended and enliven the proceedings
Bersih Desa showed their enthusiasm for the tradition of clean rural communities. They always meet the village streets to watch the procession of Jolen (Fig 2).

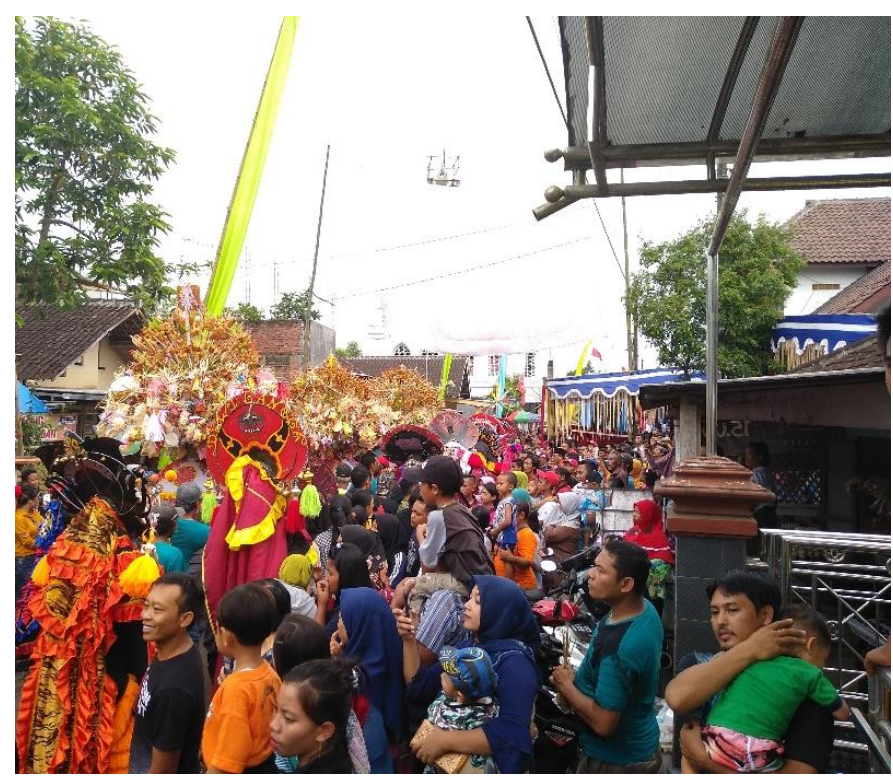

Fig 2. Procession of Jolen

Enthusiasm is high in Glanggang village communities in the implementation of the Bersih Desa. They filled the village streets to witness the Bersih Desa. The enthusiasm of the people who enliven the Bersih Desa tradition by attending a series of events for their desire to get a blessing [16]; [17], Blessing is expected by society because they crave abundant harvests and away from pests.

\section{CONCLUSION}

The enthusiasm of the community in the implementation of Bersih Desa tradition is quite high. The high enthusiasm of people can see from some form of a given society. The first form is a financial contribution. This form is to facilitate the efforts for the achievement of the community. The second form is the energy and time that is meant to relieve the burden together. Contribution of labor and time can make a job will be lighter and quickly resolved. The third form is in the form of donations consumption. The enthusiasm in this form usually has been recognized by the public without their orders. Besides enthusiasm also can take the form of public attendance to witness the Bersih Desa tradition.

\section{REFERENCES}

[1] P. Sztompka, Sosiologi Perubahan Sosial, Jakarta: Prenada Media, 2017.

[2] D. R. Pratama, "Keunikan Budaya Minangkabau dalam Novel Tenggelamnya kapal Van Der Wijck Karya Hamka dan Strategi Pemasarannya dalam Konteks Masyarakat Ekonomi Asean," Education and Language Journal, vol. 1, no. 1, pp. 221-235, 2017.

[3] A. Atsar, "Perlindungan Hukum Terhadap Pengetahuan dan Ekspresi Budaya Tradisional untuk Meningkatkan Kesejahteraan Masyarakat Ditinjau dari Undang-Undang No. 5 Tahun 2017 Tentang Pemajuan 
[12] A. Amborowati, "Aspek Nilai-nilai Sosial pada Tradisi Bersih Desa Julungan (Studi Kasus pada Pelaksanaan Tradisi Bersih Desa Julungan di Desa Kalisoro Kecamatan Tawangmangu Kabupaten Karanganyar)," 2013. [Online]. Available: http://eprints.ums.ac.id. [Accessed 3 Oktober 2018].

Kebudayaan dan Undang-Undang No. 28 Tahun 2014 Tentang Hak Cipta," Jurnal Law Reform, vol. 13, no. 2, pp. 284-299, 2017.

[4] A. Yulianto, "Upacara Adat Bersih Desa Mbah Bregas di Desa Margoagung Kecamatan Seyegan Kabupaten Sleman," 2011. [Online]. Available: http://digilib.uin-suka.ac.id. [Accessed 3 Oktober 2018].

[5] H. Bratasiswara, Bauwarna Adat Tatacara Jawa, Jakarta: Yayasan Sunurat, 2000.

[6] H. T. Lelono, "Ruwatan Tradition: Bersih Desa, Local Wisdom of Disaster Mitigation," Barkala Arkeologi, vol. 35, no. 2, pp. 145-162, 2015.

[7] A. A. Setyawati and P. Lestari, "Partisipasi Masyarakat dalam Upacara Merti Dusun (Studi Upacara Merti Dusun di Dusun Mantup, Desa Baturetno, Kecamatan Bangunpatan, Kabupaten Bantul)," E-Societas, vol. 5, no. 5, pp. 1-16, 2016.

[8] R. Adhitia, "Partisipasi Masyarakat dalam Tradisi Bersih Desa (Studi Kasus di Kampung Bibis Kulon, Kelurahan Gilingan, Kecamatan Banjarsari, Surakarta)," 2009. [Online]. Available: https://anzdoc.com. [Accessed 3 Oktober 2018].

[9] Sugiyono, Metode Penelitian Pendidikan (Pendekatan Kuantitatif, Kualitatif, dan R\&D), Bandung: CV. Alfabeta, 2017.

[10] M. B. Miles and A. M. Huberman, Analisis Data Kualitas, Buku Sumber Tentang Metode-Metode Baru, Jakarta: Universita Indonesia Press, 2014.

[11] N. R. Sulistyorini, "Partisipasi MAsyarakat dalam Pengelolaan Sampah di Lingkungan Margaluyu Kelurahan Cicurug," Social Work Journal, vol. 5, no. 1, pp. 1-9, 2015.
[13] T. S. M. a. C. M. Maloka, "Community Participation in Local Government Planning Processes: A Paramount Step Towards a Successful Service Delivery," Mediterranean Jurnal of Social Sciences, vol. 5, no. 16, pp. 652-657, 2014.

[14] M. Rolitia, "Nilai Gotong Royong untuk Memperkuat Solidaritas dalam Kehidupan Masyarakat Kampung Naga," Jurnal Societas, vol. 6, no. 1, pp. 1-10, 2016

[15] S. Yamada, "Determinants of 'community participation': the tradition of local initiatives and the institutionalization of school management committees in Oromia Region, Ethiopia," A Journal of Comparative and International Education, pp. 1-23, 2013.

[16] D. Syarifudin and L. Nurlatipah, "Daya Tarik Wisata Upacara Tradisional Hajat Laut Sebagai Nilai Budaya Masyarakat Batu Karas," Jurnal Manajemen Resort dan Leisure, vol. 12, no. 1, pp. 100-110, 2015.

[17] D. Adom, "Promoting Cultural Traditions, Social Inclusion and Local Community Participation in Enviromental Development Schemes," Global Journal of Science Frontier Research, vol. 17, no. 2, pp. 7-20, 2017. 